\title{
Synthesis of quinoline derivatives from the reaction of aminobenzophenones and acetylenic esters in the presence of $\mathrm{SnO} 2$ nanoparticles
}

\author{
Mohammad Qandalee ${ }^{1 *}$, Mohammad Alikarami $^{2}$, Hossein Mighani ${ }^{3}$, Sakineh Asghari ${ }^{4}$, Shahin Beikjani ${ }^{5}$ \\ and Mehdi Hatami ${ }^{6}$
}

\begin{abstract}
Nano $\mathrm{SnO}_{2}$ catalyzes the two-component reaction of 2-aminobenzophenones with acetylenic mono or diesters under mild conditions to afford quinoline derivatives in high yields. $\mathrm{Nano} \mathrm{SnO}_{2}$ shows high activity when used as surface catalyst for the synthesis of quinoline derivatives.
\end{abstract}

Keywords: Nano SnO2; Acetylenic esters; Quinoline; 2-Aminobenzophenones

\section{Background}

Nanocatalysis has an important role in the chemistry of nanoscience [1-4]. Many nanoparticles are used as the materials that can catalyze various chemical reactions. In some cases, nanoparticles are put on the surface since this facilitates recovery of the catalyst [5]. In addition, in several cases, users can increase the selectivity because of the high synergistic interaction between nanoparticle and solid supports [6,7]. The applications of $\mathrm{SnO}_{2}$ are in the semiconductors, and it has been widely used as gas sensor [8], solar cells [9], lithium battery and use in the materials [10], and catalysts [11]. In the area of nanocatalysis, tin oxide $\left(\mathrm{SnO}_{2}\right)$ is one of the most extensively studied materials [12]. Quinoline derivatives are one of the most applicable products in the chemistry of anti-hypertensive and anti-inflammatory, with tyrosine-kinase PDGf-RTK as an inhibitor agent [13-21]. Due to these uses, there has been an increasing interest in the development of quinoline synthesis. There are various general methods for the synthesis of this heterocycle such as Skraup, Friedlandear, Dobner-von Miller, Combes, Pfitzinger, and Conrad-Limpach [22-26]. These classical syntheses are frequently used for the preparation of pharmaceutical agents, ligands, and functional materials containing a quinoline skeleton [27]. Previously, we have reported the synthesis of 4-arylquinolines via

\footnotetext{
* Correspondence: mqandalee@yahoo.com

'Department of biology, Garmsar branch, Islamic Azad University, Garmsar, Iran Full list of author information is available at the end of the article
}

a three-component reaction of acetylenic esters and 2 -aminobenzophenone derivatives in the presence of triphenylphosphine (Scheme 1) [28].

\section{Methods}

${ }^{1} \mathrm{H}$ NMR spectra were recorded on DRX-400AVANCE spectrometer, Bruker AXS, Inc., Karlsruhe, Germany, at $400 \mathrm{MHz}$; infrared (IR) spectra were recorded on a Shimadzu IR-470 spectrometer, Kyoto, Japan. Nano $\mathrm{SnO}_{2}$ powder was achieved from NanoPac Persia Co., Isfahan, Iran. Thin layer chromatography (TLC) was carried out on Fluka Silica gel TLC- cards, St. Louis, MO, USA. All of the other reagents and solvents were used as received from commercial suppliers. A transmission electron microscope (TEM) (ZEISS EM900 operating at $50 \mathrm{kV}$, Carl Zeiss AG, Germany) was used to observe the morphology and size of the nanoparticles. The XRD pattern was acquired using a D8 ADVANCE, Bruker. The diffractograms were measured for $2 \theta$, in the range of 10 to $80^{\circ}$, using $\mathrm{Cu} \mathrm{K} \alpha$ incident beam $(\lambda=1.51418 \AA)$.

General procedure for the preparation of 4-arylquinolines (exemplified by $3 a$ )

To a stirred mixture of 2-aminobenzophenone $(2 \mathrm{mmol})$ and acetylenic ester $(2 \mathrm{mmol})$ in EtOAc, $5 \mathrm{ml} \mathrm{SnO}_{2}$ nanoparticles ( $5 \mathrm{~mol} \%$ ) was added. The reaction mixture was refluxed for $1 \mathrm{~h}$. The progress of the reaction was monitored by TLC. After completion of the reaction, the solid product was filtered and purified by 


$$
\begin{aligned}
& \text { (eflux } \\
& \mathrm{E}_{1}=\mathrm{H}, \mathrm{CO}_{2} \mathrm{R} \quad \mathrm{X}=\mathrm{H}, \mathrm{Cl} \\
& \mathrm{E}_{2}=\mathrm{CO}_{2} \mathrm{R} \quad \mathrm{Y}=\mathrm{H}, \mathrm{F}, \mathrm{Cl}
\end{aligned}
$$

Scheme 1 Reaction of acetylenic esters and 2-aminobenzophenone derivatives in the presence of triphenylphosphine.

dissolving in chloroform, and the nanocatalyst was removed by a centrifuge and pure product 3a was obtained by removing the solvent. The nanocatalyst was recovered to be reused in subsequent reactions without losing any activity. The structure of the product was confirmed by melting point, IR, and ${ }^{1} \mathrm{H}$ NMR spectra. The results were compared with authentic samples.

- Dimethyl 4-phenyl-2,3-quinolinedicarboxylate (3a): White powder; yield: $90 \%$. mp $122^{\circ} \mathrm{C}$ to $124^{\circ} \mathrm{C}$. IR $(\mathrm{KBr})\left(v_{\max } / \mathrm{cm}^{-1}\right): 3,055\left(\mathrm{C}_{s p 2}-\mathrm{H}\right), 2,994\left(\mathrm{C}_{s p 3}-\mathrm{H}\right)$, $1,725(\mathrm{CO}) ;{ }^{1} \mathrm{H}$ NMR $\left(400 \mathrm{MHz}, \mathrm{CDCl}_{3}\right): \delta_{\mathrm{H}} 3.61$ (s, 3H, OCH), 4.04 (s, 3H, OCH), $7.34\left(\mathrm{dd},{ }^{3} J_{\mathrm{HH}}=\right.$ $\left.6.4 \mathrm{~Hz},{ }^{3} J_{\mathrm{HH}}=2.0 \mathrm{~Hz}, 2 \mathrm{H}, 2 \mathrm{CH}\right), 7.47\left(\mathrm{~d},{ }^{3} J_{\mathrm{HH}}=2.0\right.$ $\mathrm{Hz}, 2 \mathrm{H}, 2 \mathrm{CH}), 7.48\left(\mathrm{t},{ }^{3} \mathrm{~J}_{\mathrm{HH}}=6.4 \mathrm{~Hz}, 1 \mathrm{H}, \mathrm{CH}\right), 7.55$ $\left(\mathrm{t},{ }^{3} J_{\mathrm{HH}}=7.7 \mathrm{~Hz}, 1 \mathrm{H}, \mathrm{CH}\right), 7.62\left(\mathrm{~d},{ }^{3} J_{\mathrm{HH}}=7.7 \mathrm{~Hz}\right.$, $1 \mathrm{H}, \mathrm{CH}), 7.79\left(\mathrm{ddd},{ }^{3} \mathrm{~J}_{\mathrm{HH}}=8.5 \mathrm{~Hz},{ }^{3} J_{\mathrm{HH}}=7.7 \mathrm{~Hz},{ }^{4} J_{\mathrm{HH}}\right.$ $=1.4 \mathrm{~Hz}, 1 \mathrm{H}, \mathrm{CH}), 8.3\left(\mathrm{~d},{ }^{3} J_{\mathrm{HH}}=8.5 \mathrm{~Hz}, 1 \mathrm{H}, \mathrm{CH}\right)$.
- Diethyl 4-phenyl-2,3-quinolinedicarboxylate (3b): White powder; yield: $87 \% . \mathrm{mp} 96^{\circ} \mathrm{C}$ to $98^{\circ} \mathrm{C}$. IR $(\mathrm{KBr})\left(v_{\max } / \mathrm{cm}^{-1}\right): 3,032\left(\mathrm{C}_{s p 2}-\mathrm{H}\right), 2,985\left(\mathrm{C}_{s p 3}-\mathrm{H}\right)$, 1,728(CO); ${ }^{1} \mathrm{H}$ NMR (400 MHz, $\left.\mathrm{CDCl}_{3}\right): \delta_{\mathrm{H}} 0.96$ $\left(\mathrm{t},{ }^{3} \mathrm{~J}_{\mathrm{HH}}=7.1 \mathrm{~Hz}, \mathrm{H}, \mathrm{CH}_{3}\right), 1.43\left(\mathrm{t},{ }^{3} \mathrm{~J}_{\mathrm{HH}}=7.1 \mathrm{~Hz}\right.$, $\left.3 \mathrm{H}, \mathrm{CH}_{3}\right), 4.06\left(\mathrm{q},{ }^{3} \mathrm{~J}_{\mathrm{HH}}=7.1 \mathrm{~Hz}, 2 \mathrm{H}, \mathrm{OCH}_{2}\right), 4.50$ $\left(\mathrm{q},{ }^{3} J_{\mathrm{HH}}=7.1 \mathrm{~Hz}, 2 \mathrm{H}\right), 7.33\left(\mathrm{dd},{ }^{3} J_{\mathrm{HH}}=6.5 \mathrm{~Hz}\right.$, $\left.{ }^{3} J_{\mathrm{HH}}=2.2 \mathrm{~Hz}, 2 \mathrm{H}, 2 \mathrm{CH}\right), 7.45\left(\mathrm{~d},{ }^{3} \mathrm{~J}_{\mathrm{HH}}=2.2 \mathrm{~Hz}\right.$, $2 \mathrm{H}, 2 \mathrm{CH}), 7.46\left(\mathrm{t},{ }^{3} \mathrm{~J}_{\mathrm{HH}}=6.5 \mathrm{~Hz}, 1 \mathrm{H}, \mathrm{CH}\right), 7.53$ $\left(\mathrm{t},{ }^{3} \mathrm{~J}_{\mathrm{HH}}=7.8 \mathrm{~Hz}, 1 \mathrm{H}, \mathrm{CH}\right), 7.59\left(\mathrm{~d},{ }^{3} \mathrm{~J}_{\mathrm{HH}}=7.8 \mathrm{~Hz}\right.$, $1 \mathrm{H}, \mathrm{CH}), 7.79\left(\mathrm{ddd},{ }^{3} \mathrm{~J}_{\mathrm{HH}}=8.5 \mathrm{~Hz},{ }^{3} J_{\mathrm{HH}}=7.8 \mathrm{~Hz}\right.$, $\left.{ }^{4} J_{\mathrm{HH}}=1.4 \mathrm{~Hz}, 1 \mathrm{H}, \mathrm{CH}\right), 8.29\left(\mathrm{~d},{ }^{3} J_{\mathrm{HH}}=8.5 \mathrm{~Hz}\right.$ $1 \mathrm{H}, \mathrm{CH})$.

- Methyl 4-phenyl-2-quinolinecarboxylate (3c): White powder; yield: $60 \% \mathrm{mp} 101^{\circ} \mathrm{C}$ to $103^{\circ} \mathrm{C}$. IR $(\mathrm{KBr})\left(v_{\max } / \mathrm{cm}^{-1}\right): 3,010\left(\mathrm{C}_{s p 2}-\mathrm{H}\right), 2,995\left(\mathrm{C}_{s p 3}-\mathrm{H}\right)$, 1,725 (CO); ${ }^{1} \mathrm{H}$ NMR $\left(400 \mathrm{MHz}, \mathrm{CDCl}_{3}\right): \delta_{\mathrm{H}} 4.07$ (s, $\left.3 \mathrm{H}, \mathrm{OCH}_{3}\right), 7.49$ to $7.54(\mathrm{~m}, 5 \mathrm{H},-\mathrm{Ph}), 7.58$ $\left(\mathrm{dd},{ }^{3} J_{\mathrm{HH}}=8.3,{ }^{3} J_{\mathrm{HH}}=7.7 \mathrm{~Hz}, J_{\mathrm{HH}}=1.1 \mathrm{~Hz}, 1 \mathrm{H}, \mathrm{CH}\right)$,<smiles>[Y]c1ccccc1C(=O)c1c(N)ccc([X])c1CC(=O)OCC(=O)OCC</smiles>

Scheme 2 2-aminobenzophenones 2 react with acetylenic mono or diesters 1 in the presence of nano $\mathrm{SnO}_{2}$. 
Table 1 Synthesis of 4-arylquinolines derivatives

\begin{tabular}{cccccc}
\hline Product & $\mathbf{E}_{\mathbf{1}}$ & $\mathbf{E}_{\mathbf{2}}$ & $\mathbf{X}$ & $\mathbf{Y}$ & Yield (\%) \\
\hline $\mathbf{3 a}$ & $\mathrm{CO}_{2} \mathrm{Me}$ & $\mathrm{CO}_{2} \mathrm{Me}$ & $\mathrm{H}$ & $\mathrm{H}$ & 90 \\
$\mathbf{3 b}$ & $\mathrm{CO}_{2} \mathrm{Et}$ & $\mathrm{CO}_{2} \mathrm{Et}$ & $\mathrm{H}$ & $\mathrm{H}$ & 87 \\
$\mathbf{3} \mathbf{c}$ & $\mathrm{H}$ & $\mathrm{CO}_{2} \mathrm{Me}$ & $\mathrm{H}$ & $\mathrm{H}$ & 60 \\
$\mathbf{3 d}$ & $\mathrm{H}$ & $\mathrm{CO}_{2} \mathrm{Et}$ & $\mathrm{H}$ & $\mathrm{H}$ & 65 \\
$\mathbf{3 e}$ & $\mathrm{CO}_{2} \mathrm{Me}$ & $\mathrm{CO}_{2} \mathrm{Me}$ & $\mathrm{Cl}$ & $\mathrm{H}$ & 80 \\
$\mathbf{3 f}$ & $\mathrm{CO}_{2} \mathrm{Et}$ & $\mathrm{CO}_{2} \mathrm{Et}$ & $\mathrm{Cl}$ & $\mathrm{H}$ & 90 \\
$\mathbf{3 g}$ & $\mathrm{H}$ & $\mathrm{CO}_{2} \mathrm{Me}$ & $\mathrm{Cl}$ & $\mathrm{H}$ & 70 \\
$\mathbf{3 h}$ & $\mathrm{H}$ & $\mathrm{CO}_{2} \mathrm{Et}$ & $\mathrm{Cl}$ & $\mathrm{H}$ & 75 \\
$\mathbf{3 i}$ & $\mathrm{CO}_{2} \mathrm{Me}$ & $\mathrm{CO}_{2} \mathrm{Me}$ & $\mathrm{Cl}$ & $\mathrm{Cl}$ & 74 \\
$\mathbf{3 j}$ & $\mathrm{CO}_{2} \mathrm{Et}$ & $\mathrm{CO}_{2} \mathrm{Et}$ & $\mathrm{Cl}$ & $\mathrm{Cl}$ & 87 \\
$\mathbf{3 k}$ & $\mathrm{CO}_{2} \mathrm{Me}$ & $\mathrm{CO}_{2} \mathrm{Me}$ & $\mathrm{Cl}$ & $\mathrm{F}$ & 92 \\
$\mathbf{3}$ & $\mathrm{CO}_{2} \mathrm{Et}$ & $\mathrm{CO}_{2} \mathrm{Et}$ & $\mathrm{Cl}$ & $\mathrm{F}$ & 95 \\
\hline
\end{tabular}

$7.7\left(\mathrm{ddd},{ }^{3} J_{\mathrm{HH}}=8.4 \mathrm{~Hz},{ }^{3} J_{\mathrm{HH}}=7.7 \mathrm{~Hz}\right.$,

$\left.{ }^{4} J_{\mathrm{HH}}=1.4 \mathrm{~Hz}, 1 \mathrm{H}, \mathrm{CH}\right), 7.96\left(\mathrm{~d},{ }^{3} J_{\mathrm{HH}}=8.3 \mathrm{~Hz}\right.$, $1 \mathrm{H}, \mathrm{CH}), 8.14\left(\mathrm{~s}, 1 \mathrm{H}, \mathrm{CH}_{3}\right), 8.36\left(\mathrm{~d},{ }^{3} \mathrm{~J}_{\mathrm{HH}}=8.4\right.$

$\mathrm{Hz}, 1 \mathrm{H}, \mathrm{CH})$.

- Ethyl 4-phenyl-2-quinolinecarboxylate (3d): White powder; yield: $65 \%$. mp $125^{\circ} \mathrm{C}$ to $127^{\circ} \mathrm{C}$. IR $(\mathrm{KBr})$ $\left(v_{\max } / \mathrm{cm}^{-1}\right): 3,045\left(\mathrm{C}_{s p 2}-\mathrm{H}\right), 2,985\left(\mathrm{C}_{s p 3}-\mathrm{H}\right)$, $1,724(\mathrm{CO})$.

- Dimethyl 6-chloro-4-phenyl-2,3quinolinedicarboxylate (3e): White powder; yield: $80 \%$. mp $158^{\circ} \mathrm{C}$ to $160^{\circ} \mathrm{C}$. IR $(\mathrm{KBr})\left(v_{\max } / \mathrm{cm}^{-1}\right)$ : $3,074\left(\mathrm{C}_{\mathrm{sp} 2}-\mathrm{H}\right), 2,958\left(\mathrm{C}_{\mathrm{sp} 3}-\mathrm{H}\right), 1,732$ and 1,729 (CO).

- Diethyl 6-chloro-4-phenyl-2,3quinolinedicarboxylate (3f): White powder; yield:
90\%. mp $163^{\circ} \mathrm{C}$ to $165^{\circ} \mathrm{C}$. IR $(\mathrm{KBr})\left(v_{\max } / \mathrm{cm}^{-1}\right)$ : 3,075 $\left(\mathrm{C}_{s p 2}-\mathrm{H}\right), 2,988\left(\mathrm{C}_{s p 3}-\mathrm{H}\right), 1,739$ and 1,724 (CO).

- Methyl 6-chloro-4-phenyl-2-quinolinecarboxylate (3g): White powder; yield: $70 \% . \mathrm{mp} 177^{\circ} \mathrm{C}$ to $179^{\circ} \mathrm{C}$. IR $(\mathrm{KBr})\left(v_{\max } / \mathrm{cm}^{-1}\right): 3,054\left(\mathrm{C}_{s p 2}-\mathrm{H}\right), 2,998\left(\mathrm{C}_{s p 3^{-}}-\mathrm{H}\right)$, $1,719(\mathrm{CO})$.

- Ethyl 6-chloro-4-phenyl-2-quinolinecarboxylate (3h): Yellow powder; yield: $75 \% . \mathrm{mp} 171^{\circ} \mathrm{C}$ to $173^{\circ} \mathrm{C}$. IR $(\mathrm{KBr})\left(v_{\max } / \mathrm{cm}^{-1}\right): 3,064\left(\mathrm{C}_{s p 2}-\mathrm{H}\right)$, 2,983 $\left(\mathrm{C}_{s p 3}-\mathrm{H}\right), 1,729(\mathrm{CO})$.

- Dimethyl 6-chloro-4-(2-chlorophenyl)-2,3quinolinedicarboxylate (3i): Yellow powder; yield: $74 \%$. mp $190^{\circ} \mathrm{C}$ to $192^{\circ} \mathrm{C}$. IR $(\mathrm{KBr})\left(v_{\max } / \mathrm{cm}^{-1}\right)$ : $3,070\left(\mathrm{C}_{s p 2}-\mathrm{H}\right), 2,985\left(\mathrm{C}_{s p 3}-\mathrm{H}\right), 1,729$ and $1,720(\mathrm{CO})$.

- Diethyl 6-chloro-4-(2-chlorophenyl)-2,3quinolinedicarboxtlate (3j): White powder; yield: $87 \%$. $\mathrm{mp} 127^{\circ} \mathrm{C}$ to $129^{\circ} \mathrm{C}$. IR $(\mathrm{KBr})\left(v_{\max } / \mathrm{cm}^{-1}\right): 3,074$ $\left(\mathrm{C}_{s p 2}-\mathrm{H}\right), 2,983\left(\mathrm{C}_{s p 3}-\mathrm{H}\right), 1,729$ and $1,724(\mathrm{CO})$.

- Dimethyl 6-chloro-4-(2-fluorophenyl)-2,3quinolinedicarboxylate (3k): White powder; yield: 92\%. mp $210^{\circ} \mathrm{C}$ to $212^{\circ} \mathrm{C}$. IR $(\mathrm{KBr})\left(v_{\max } / \mathrm{cm}^{-1}\right)$ : $3,079\left(\mathrm{C}_{s p 2}-\mathrm{H}\right), 2,953\left(\mathrm{C}_{s p 3}-\mathrm{H}\right), 1,729$ and 1,718 (CO).

- Diethyl 6-chloro-4-(2-fluorophenyl)-2,3quinolinedicarboxylate (3l): White powder; yield: $95 \%$. mp $135^{\circ} \mathrm{C}$ to $137^{\circ} \mathrm{C}$. IR $(\mathrm{KBr})\left(v_{\max } / \mathrm{cm}^{-1}\right)$ : 3,084 $\left(\mathrm{C}_{\mathrm{sp2} 2}-\mathrm{H}\right), 2,983\left(\mathrm{C}_{\mathrm{sp} 3}-\mathrm{H}\right), 1,729$ and 1,719 (CO).

\section{Results and discussion}

In this work, we report a methodology reaction in which 2 -aminobenzophenones 2 react with acetylenic

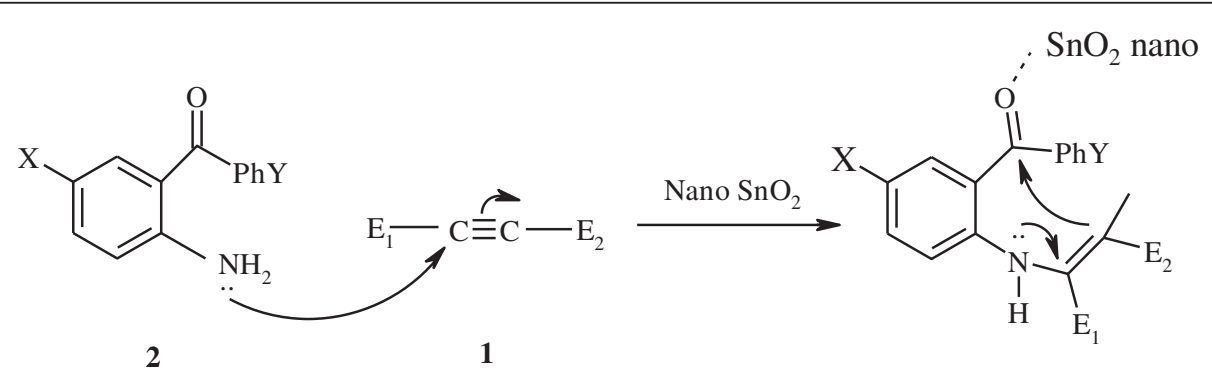

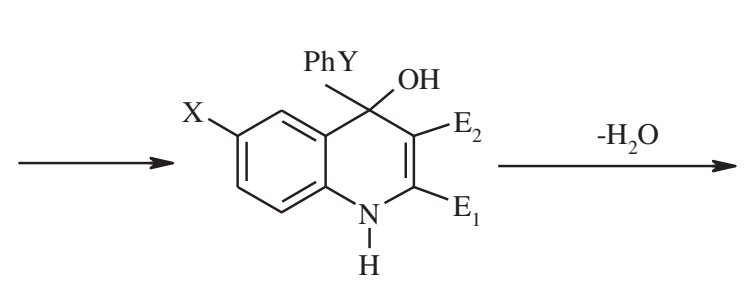

4<smiles>[X]c1ccc2nc(F)c(F)c(-c3ccccc3[Y])c2c1</smiles>

3

Scheme 3 Mechanism of the reaction. 
mono or diesters $\mathbf{1}$ in the presence of nano $\mathrm{SnO}_{2}$ (Scheme 2).

The yields of the two component reactions show that nano $\mathrm{SnO}_{2}$ catalyzes these reactions efficiently (Table 1 ). It was found that nano $\mathrm{SnO}_{2}$ acts as both site of catalysis and a support for this system due to their high surface area. A possible mechanism of the reaction is shown in Scheme 3. It is reasonable to assume that the initial attack of nucleophilic amine to the acetylenic ester leads to the formation of intermediate $\mathbf{4}$ on the surface of nano $\mathrm{SnO}_{2}$ which can act as Lewis acid to increase the electrophilicity of the carbonyl group of 2-aminobenzophenone. Then, the product 3 is formed by loss of one molecule of water under reflux condition (Scheme 3).

In the procedure of optimizing the reaction conditions, we monitored the solvent effect, temperature dependency, and the amount of nanocatalyst. To study the optimized condition of the reaction parameters, the reaction between 2-aminobenzophenone and DMAD was considered as the model reaction. The effect of different solvents was monitored, and the excellent results were obtained when the reaction has been carried out in EtOAc. The temperature monitoring showed that the best temperature for this reaction is the reflux condition for $1 \mathrm{~h}$. Also, when the reaction was scaled up to $5 \mathrm{~mol} \%$ of nano $\mathrm{SnO}_{2}$, the highest yield was achieved (Table 2), and in the absence of $\mathrm{SnO}_{2}$ catalyst no formation of the expected product was detected even after $3 \mathrm{~h}$.

The morphology, crystal structure, and sizes of the $\mathrm{SnO}_{2}$ nanocatalyst were characterized by X-ray diffraction and TEM analyses. The powder X-ray diffraction pattern of the reaction mixture was recorded on a Rigaku D/Max-2200 diffractometer, Shibuya-ku, Japan, equipped with horizontal goniometer in $\theta / 2 \theta$ geometry. The $\mathrm{Cu} \mathrm{K} \alpha$ ( $l=1.5418 \AA$ ) radiation was used, and the sample was scanned between $3^{\circ}$ to $80^{\circ} 2 \theta$. The sharp peaks in the diffractogram indicate that the reaction media (nano $\mathrm{SnO}_{2}$ in the dimethyl 4-phenyl-2,3-quinolinedicarboxylate)

Table 2 Optimizing the reaction condition between 2-amino benzophenone and DMAD

\begin{tabular}{cccccc}
\hline Entry & $\begin{array}{c}\mathbf{N a n o ~}_{\mathbf{S n O}} \\
(\mathbf{m o l} \%)\end{array}$ & Solvent & $\begin{array}{c}\text { Temperature } \\
\left({ }^{\circ} \mathbf{C}\right)\end{array}$ & $\begin{array}{c}\text { Time } \\
(\mathbf{h})\end{array}$ & $\begin{array}{c}\text { Yield } \\
(\mathbf{\%})\end{array}$ \\
\hline 1 & 5 & Dichloromethane & 50 & 4 & 35 \\
2 & 5 & Chloroform & 60 & 4 & 40 \\
3 & 5 & Acetone & 60 & 4 & 48 \\
4 & 5 & Toluene & 80 & 4 & 61 \\
5 & 2 & Ethyl acetate & 80 & 2.5 & 80 \\
6 & 3 & Ethyl acetate & 80 & 2 & 85 \\
7 & 5 & Ethyl acetate & rt & 3 & 90 \\
8 & 5 & Ethyl acetate & 80 & 1 & 90 \\
9 & 10 & Ethyl acetate & 80 & 1 & 90 \\
\hline
\end{tabular}

contain crystalline species. There are several major peaks with $2 \theta$ values of $26.63,33.91,37.94,42.61,51.80,54.77$, and 57.83, corresponding to $\mathrm{SnO}_{2}$ crystal planes of $\left(\begin{array}{lll}1 & 0 & 1\end{array}\right)$, (1 110$),\left(\begin{array}{lll}1 & 1 & 1\end{array}\right),\left(\begin{array}{lll}2 & 1 & 0\end{array}\right),\left(\begin{array}{lll}2 & 1 & 1\end{array}\right),\left(\begin{array}{lll}2 & 2 & 0\end{array}\right)$, and (0 0 2), respectively. All reflections of $\mathrm{SnO}_{2}$ nanoparticles show tetragonal rutile structure (JCPDS 41-1445).

TEM images of the $\mathrm{SnO}_{2}$ nanocatalyst in the reaction mixture (nano $\mathrm{SnO}_{2}$ in the dimethyl 4-phenyl-2,3quinolinedicarboxylate) in different scales $(50,100,150$, 200, and $300 \mathrm{~nm}$ ) were obtained. Also, using the bright field technique, the nanoparticles were observed; the nanoparticles look distinctly darker than the organic phase due to the much higher electron density, the nanoparticles clearly distinguishable from organic media. The obtained pictures showed that the nanoparticles are in good dispersion state, and the nanoparticles are in the range of 70 to $95 \mathrm{~nm}$.

\section{Conclusions}

In conclusion, we have reported an efficient procedure for the synthesis of quinoline derivatives using $\mathrm{SnO}_{2}$ nanoparticles as a non-toxic and inexpensive heterogeneous nanocatalyst. The method offers advantages such as ease of the work-up, low loading of catalyst, high yields of products and short reaction times.

\section{Author details}

'Department of biology, Garmsar branch, Islamic Azad University, Garmsar, Iran. 2Department of Chemistry, llam Branch, Islamic Azad University, Ilam, Iran.

${ }^{3}$ Department of Chemistry, Faculty of science, Golestan University, Gorgan, Iran. ${ }^{4}$ Department of Chemistry, Ayatollah Amoli Branch, Islamic Azad University, Amol, Iran. ${ }^{5}$ Department of Organic Chemistry, Faculty of Chemistry, University of Mazandaran, Babolsar 47416, Iran. ${ }^{6}$ Department of Marine Chemistry, Faculty of Marine Science, Khorramshahr University of Marine Science and Technology, Khorramshahr, Iran.

Received: 1 December 2012 Accepted: 23 July 2013

Published: 23 Aug 2013

\section{References}

1. Corma, A, Serna, P: Chemoselective Hydrogenation of Nitro Compounds with Supported Gold Catalysts, Science 313, 332 (2006).

2. Enache, DI, Edwards, JK, Landon, P, Solsona-Espriu, B, Carley, AF, Herzing, AA, Watanabe, M, Kiely, CJ, Knigh, DW, Hutchings, GJ: Science $311,362(2006)$

3. Hughes, MD, Xu, J, Jenkins, P, McMorn, P, Landon, P, Enache, DI, Carley, AF, Attard, GA, Hutchings, GJ, King, F, Stitt, EH, Johnston, P, Griffin, K, Kiely, CJ: Nature 437, 1132 (2005)

4. Liang, HP, Zhang, HM, Hu, JS, Guo, YG, Wan, YL, Bai, CL: Angew. Chem. Int 43, 1540 (2004)

5. Astruc, D, Lu, F, Aranzaes, JR: Angew. Chem. Int. Ed. 44, 7852 (2005)

6. Valden, M, Lai, X, Goodman, DW: Science 281, 1647 (1998)

7. Huang, J, Jiang, T, Gao, HX, Han, BX, Liu, ZM, Wu, WZ, Chang, YH, Zhao, GY: Angew. Chem. Int. Ed. 43, 1397 (2004)

8. Li, C, Bi, L: F. Shaming. J. Rare Earths. 25, 505 (2007)

9. El-Etre, AY, Reda, SM: Appl. Surf. Sci. 256, 6601 (2010)

10. Li, C, Wei, W, Fang, S, Wang, H, Zhang, Y, Gui, Y: R. Chen. J. Power Sources. 195, 2939 (2010)

11. Arpita, S, Sudip, KG, Panchanan, P: J. Mol. Catalysis A: Chemical. 327, $73(2010)$

12. Modou, MJ, Roy, S: Morrison Chemical Sensing with Solid State Devices. Academic Press, New York (1989) 
13. Barton, D, Ollis, WD: Comprehensive organic chemistry: the synthesis and reaction of organic compounds, vol 4, pp. 166-203. Pergamon, Oxford (1979)

14. Desai, PK, Desai, P, Machhi, D, Desai, CM, Patel, D: Indian J. Chem. 35,871 (1996)

15. Sonza, MV, Vasconcelos, TPA: Quim. Nova. 28, 678 (2005)

16. Hirano, Y, Uehara, M, Saeki, K, Kato, T, Takahashi, K, Mizutani, T: J. Health. Sci. 48, 118 (2002)

17. Larsen, RD, Corley, EG, King, AO, Carrol, JD, Davis, P, Verhoevea, TR, Reider, PJ, Lablle, M, Ganthier, JY, Xiang, YB, Zamboni, RJ: J. Org. Chem. 61, 3398 (1996)

18. Chen, YL, Fang, KC, Sheu, JY, Hsu, SL, Tzeng, CC: J. Med. Chem. 44(K.C Fang), 2374 (2001)

19. Kallmaya, B, Serrnivasa, S: Farmaco 53, 399 (1998)

20. Ko, TC, Hour, MJ, Liem, JC, Teng, CM, Lee, KH, Kno, SC, Huang, L: J. Bio. Org. Med. Chem. Lett. 11, 279 (2001)

21. Ferrarini, PL, Mori, C, Badwneh, M, Menera, C, Martinelli, A, Miceli, M, Ramagnoli, F, Saccomanui, G: J. Heterocycl. Chem. 34, 1501 (1997)

22. Maguire, MP, Sheets, KR, Mcverty, K, Spada, AP, Zilberstain, A: J. Med. Chem. 37, 2129 (1994)

23. Bergstrom, FW: Chem. Rev. 35, 77 (1944)

24. Edward, A: J. Org. Chem. 31, 2899 (1966)

25. Jones, G: In: Weissberger, A, Taylor, EC (eds.) The Chemistry of Heterocyclic Compounds, vol. 32, part I, pp. 93-318. Wiley, Chichester (1997)

26. Reitsema, RH: Chem. Rev. 43, 43 (1948)

27. Jones, G: In: Kat-ritzky, AP, Rees, CW, Scriven, EE (eds.) Comprehensive Heterocyclic Chemistry, vol. 5, chap. 5, p. 167. Pergamon, Oxford (1996)

28. Asghari, S, Qandalee, M, Naderi, Z: Z. Sobhaninia. Mol. Divers. $14,569(2010)$

10.1186/2228-5326-3-49

Cite this article as: Qandalee et al:: Synthesis of quinoline derivatives from the reaction of aminobenzophenones and acetylenic esters in the presence of SnO2 nanoparticles. International Nano Letters 2013, 3:49

\section{Submit your manuscript to a SpringerOpen ${ }^{\circ}$ journal and benefit from:}

- Convenient online submission

- Rigorous peer review

- Immediate publication on acceptance

- Open access: articles freely available online

- High visibility within the field

- Retaining the copyright to your article

Submit your next manuscript at $>$ springeropen.com 